\title{
Bridging literacy and curriculum: development of a thematic children's book
}

\author{
A A I N Marhaeni ${ }^{1 *}$, N Dantes ${ }^{1}$, D G Purwitha ${ }^{1}$, D A P Handayani ${ }^{2}$, and D G F \\ Wirabrata ${ }^{2}$ \\ ${ }^{123}$ Universita Pendidikan Ganesha, Indonesia \\ *ngurah_marhaeni@yahoo.com
}

\begin{abstract}
The study aimed at facilitating and promoting meningful learning in the current thematic learning approach in elementary schools through developing a K-13's content-based thematic children's book. The study used ADDIE research and development model. Product of the research was a children's book entitled Mencar (going fishing) which was meant to be used as a supplementary reading material for four graders on the subtheme Occupations Around Me. To make the book contextual, cultural aspects of Bali were also included. After completion, four reviewers containing two teachers, a writer, and an illustrator were asked to assess the quality of the book. Further, the book was tried out to twenty six students to see whether the book - when used together with the subtheme's textbook - had an effect on students' attitude, reading interest, and learning outcome. Results of the study show that the children's book Mencar was proven effective in supporting learning, including children's reading interest which is the primary goal of our national literacy movement or GLS.
\end{abstract}

\section{Introduction}

$\mathrm{K}-13$ is the name of Indonesia's school recent curriculum which has gradually taken its effect in elementary schools since 2013. The curriculum is competency based which aims at accomplishing four core competencies namely spiritual, social, cognitive, and psychomotoric. In its implementation, the curriculum takes thematic integrative approach in which a theme is divided into subthemes (generally four subthemes) which is finished in one month of instruction. The implementation of the curriculum is accompanied with thematic textbooks, one textbook for one subtheme.

Along with the implementation of the curriculum, in 2016 the Ministry of Education and Culture launched a national wide program called Gerakan Literasi Sekolah or GLS which is a school literacy movement. The primary goal of GLS is to develop literacy i.e, ability to read and write, through three main activities namely 1 ) reading intensively for fifteen minutes/day, 2) responding to a text, and 3 ) reading and writing to enhance learning in subject matters. A rough observation conducted to several elementary schools and some teachers indicated that $G L S$ is not conducted properly. The fifteen minute intensive reading only takes once a week in which students are asked to write summaries which never receive any feedback. More importantly, children's books are not sufficiently provided in the school library. One very important note for this is, that activity number 3) above cannot be facilitated because the children's books are randomly read by the students. Moreover, books in the library contain random contents, which means, the books are not deliberately selected to fulfill that 
purpose. Children's books that contain subject matter contents are not so far available. Ideally, a children's book must fulfill the three goals above. It means that $G L S$ and curriculum must be facilitated to support each other. This paper describes an effort to bridge $G L S$ and K-13 curriculum implementation through the process of developing a thematic-based children's story entitled Mencar (Going Fishing) and its effect on elementary school students' attitude, reading interest, and learning outcome as required by the sub theme Occupations Around Me.

\section{Method}

This was a research and development using ADDIE (Analyse, Design, Develop, Implement, and Evaluate) instructional model. The model was created by Florida State University in 1975.

Analyse.In this stage, an analysis was done to contents (attitude, knowledge, and skill) of the sub theme Occupations Around Me. The analysis found that the subtheme contains spiritual attitudes such as obedience to religion adherent to and gratitude; social attitudes such as respect, discipline, and responsibility; subject matter content knowledge and skills such as Citizenship, Bahasa, Science, math, social science, arts, and health and sports. It was also found that some Balinese cultural aspects can be used to support learning of the contents.Those aspects include singing the song Juru Pencar, worshipping with banten saiban(daily offering with foods) and canang(daily offering with flowers), storying and traditional games megala-galaan (a group game). The analysis shows findings of curriculum contents of the sub theme Occupations Around Me and their corresponding local cultural aspects (which included traditional games, storying, singing, and worshipping). The findings above also suggest that many local (Balinese) cultural aspects are relevant to K-13 curriculum. It can also be seen that several cultural activities reoccur to support some relevant curriculum aspects. Traditional game megala-gala, for instance, occured to support spiritual attitude obedience to adherent religion, Singing Juru Pencar, and worshipping mebanten saiban and mesegeh occured several times. Those corresponding curriculum contents and local context were used to develop the story Mencar.

Design and develop. Based on findings above, a children's book entitled Mencar was designed and developed. Table 2 below shows the design and development of the book.

Table 2. Design and development of the children's book Mencar for subtheme Occupations Around Me

\begin{tabular}{|c|c|c|c|c|}
\hline $\begin{array}{l}\text { Aspects } \\
\text { of } \\
\text { Analysis }\end{array}$ & Contents & $\begin{array}{l}\text { Cultural } \\
\text { aspects } \\
\text { involved }\end{array}$ & Examples from partsof the book & $\begin{array}{l}\text { Appearing } \\
\text { on page }\end{array}$ \\
\hline \multirow[t]{5}{*}{ Attitude } & $\begin{array}{l}\text { Obedience } \\
\text { to adherent } \\
\text { religion }\end{array}$ & $\begin{array}{l}\text { Worship with } \\
\text { banten saiban }\end{array}$ & $\begin{array}{l}\text { And Gede Bagus rushed to worship with } \\
\text { banten saiban. }\end{array}$ & 10 \\
\hline & & Grateful & $\begin{array}{l}\text { "Father, we got a lot of fish this time", said Gde } \\
\text { Bagus. } \\
\text { "Yes, Gde. We must always be grateful". Let's } \\
\text { go fishing again this afternoon". }\end{array}$ & 8 \\
\hline & $\begin{array}{l}\text { Social } \\
\text { attitude }\end{array}$ & Responsible & $\begin{array}{l}\text { Gde Bagus is responsible to clean the houseyard } \\
\text { every morning. }\end{array}$ & 6 \\
\hline & & Empathy & $\begin{array}{l}\text { Made Ayu helped her father plant coconut } \\
\text { seeds. }\end{array}$ & 16 \\
\hline & & Discipline & $\begin{array}{l}\text { Gde Bagus never forgot cleaning the houseyard } \\
\text { every morning. }\end{array}$ & 6 \\
\hline \multirow[t]{2}{*}{$\begin{array}{l}\text { Subject } \\
\text { matter }\end{array}$} & Bahasa & $\begin{array}{l}\text { Characteristics } \\
\text { of characters }\end{array}$ & Gde Bagus who was smart and brave ........ & 4 \\
\hline & $\begin{array}{l}\text { Social } \\
\text { science }\end{array}$ & $\begin{array}{l}\text { Economic } \\
\text { activities }\end{array}$ & $\begin{array}{l}\text { From a distance, Gde Bagus saw his father } \\
\text { carrying fish he caught. He was a fisherman. }\end{array}$ & 6 \\
\hline
\end{tabular}




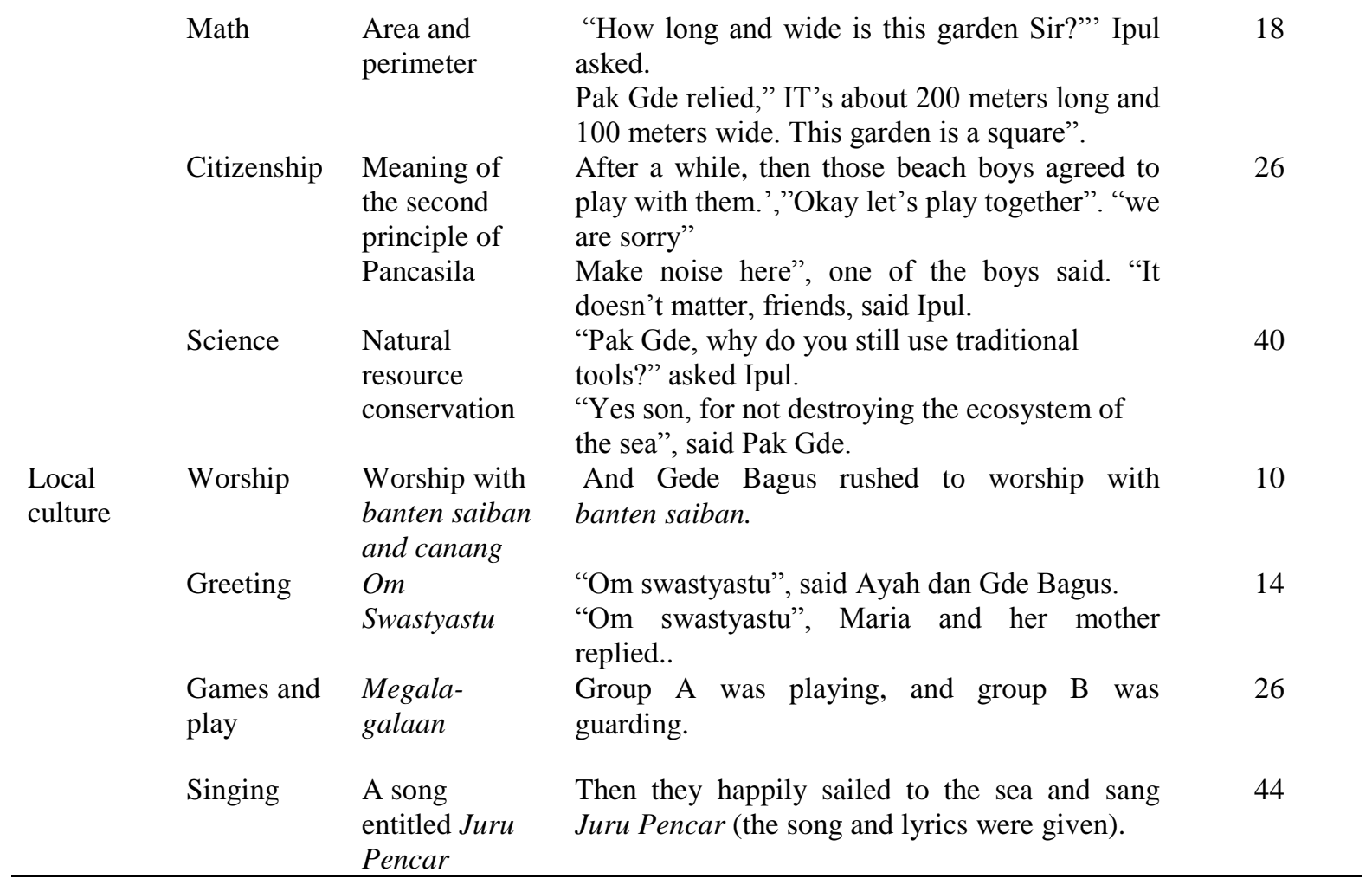

Implement. After completion, the story was tried out. Subjects of the implementation were 26 fifth grade students of No. 10 Sumerta Elementary School in Denpasar Bali. Setting of the try out was oneweek lessons of the sub theme Occupations Around Me. The scenario of the lessons using the sub theme's textbook and the children's book Mencar was as below.

Table 3. Scenario of using the book Mencar in the teaching of sub theme Occupations Around Me using the K-13 textbook

\begin{tabular}{ll}
\hline Textbook & \\
\hline Introducing the theme & $\begin{array}{l}\text { Comparing the use of } \\
\text { traditional and modern } \\
\text { technology. }\end{array}$ \\
& $\begin{array}{l}\text { Comparing kinds of } \\
\text { occupations. }\end{array}$ \\
Lesson 2 & $\begin{array}{l}\text { Area and perimeter } \\
\text { Lesson } 3\end{array}$ \\
& $\begin{array}{l}\text { Discussing the meaning } \\
\text { of the second principle } \\
\text { of Pancasila } \\
\text { Comparing } \\
\text { characteristics of } \\
\text { character }\end{array}$
\end{tabular}
Children's Book Mencar Teacher introduced the book and asked the students to read the whole book in their literacy time Identifying tools in the story used to catch fish.

Based on the story, students identify kinds of occupations such as fisherman, fish seller, architect, farmer.

Teacher asked students to open the story Mencar page 18 and together they identify area and perimeter of a garden.

Megala-gala game between the beach boys and Gde Bagus and friends

Students discussed the characteristics of characters appearing on the children's book Mencar. 
Use of natural resources

Lesson 4

Lesson 5

Lesson 6

Closure
Giving opinion about characteristics of a character

Computing area and perimeter

Discussing about economic activities and occupations

Identifying moral messages

Giving favorable and unfavorable examples of values related to the second principle of Pancasila.
Students identified and discussed natural resources in the story Mencar.

Teacher read a part of the story Mencar and brought students to a discussion about characteristics of a character in the story

Teacher brought students to compute area and perimeter of Made Ayu father's garden.

Students listed the economic activities and occupations they found in the story.

Teacher pointed to some parts of the story and asked the students to find the moral messages within.

Teacher pointed to some parts of the story and asked the students to find the values of the second principle of Pancasila.

Reading together and discussed how the students liked the story and what benefits they obtained through reading the story.

Evaluate. After one week of try out, students' attitude, reading interest, and learning outcome were assessed. Data of students' attitude and reading interest were collected through questionnaires, and data of learning outcomes were collected through tests. All instruments were validated before use. The collected data were then analyzed by using Bruning's t-test and then the results were categorized using the following criteria of effect size (ES).

Tabel 4. Category of effect size (ES)

\begin{tabular}{lc}
\hline \multicolumn{1}{c}{ Effect Size (ES) } & Category \\
\hline ES $<0,2$ & Less effective \\
$0,2 \leq E S<0,8$ & Effective \\
$0,8 \leq E S$ & Very effective \\
\hline
\end{tabular}

\section{Findings and Discussion}

3.1. Sinopsis of the children's book Mencar

The children's book Mencar is a picture story which tells about Gde Bagus a ten-year old boy with his multicultural friends Ipul, Made Ayu, Anton, and Maria. They had been good friends for a long time, together in good and bad times. One day, the friends followed Gde Bagus's father who was a fisherman go fishing. They fished happily and sang the song Juru Pencar. Along the story, some events and activities were portrayed, in which contents of the sub theme Occupations Around Me were included.

\subsection{Effectiveness of the Use of Children's Book Mencar on Grade 5 Students' Attitude, Reading Interest, and Learning outcome}


The effectiveness of the use of children's book Mencar in the lessons of sub theme Occupations Around Me toward students' attitude, reading interest, and learning outcome is shown on table 5 below.

Table 5. Summary of Try out Results $(\mathrm{N}=26)$

\begin{tabular}{lcccc}
\hline Variables assessed & Value & t-obs. & \multicolumn{2}{c}{ Effect Size } \\
& level $=2.06$ & Value & Category \\
\hline Attitude & 8.91 & significant & 1.75 & Very effective \\
Reading Interest & 4.48 & significant & 0.88 & Very effective \\
Learning Outcome & 7.78 & significant & 1.53 & Very effective \\
\hline
\end{tabular}

Graph 1. Summary of Try Out Results

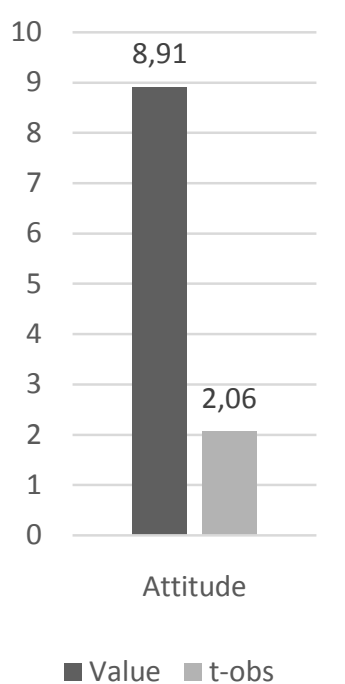

Value t-obs
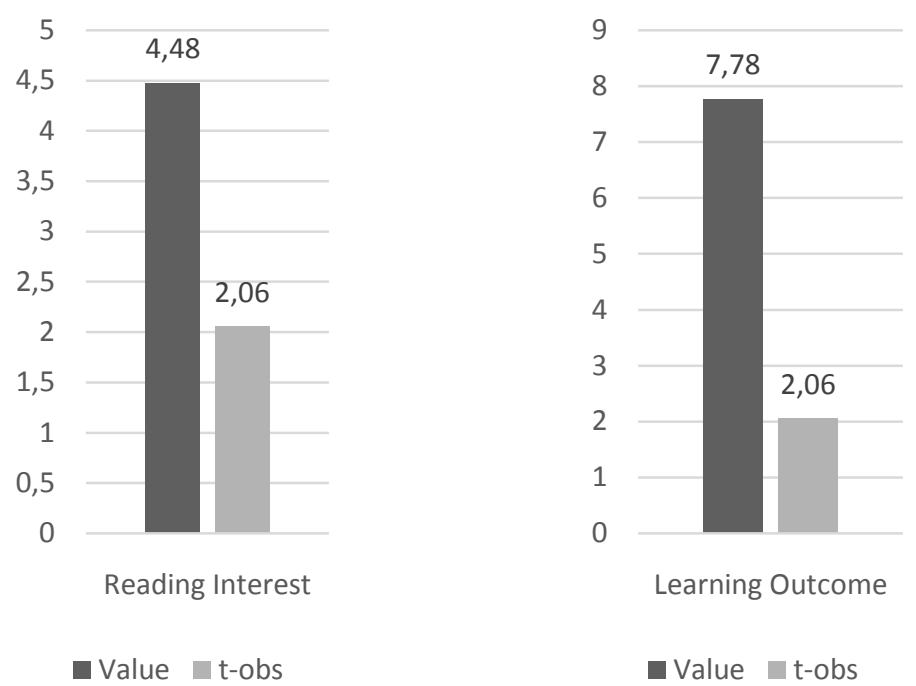

From the results of analysis as shown above, it was found that the thematic children's book Mencar was proved very effective on students' attitude. Another research finding reported the use of stories is pedagogically effective in transforming moral values [1]. A narrative presentation of values can directly model moral lessons; for instance, a child will spontaneously pray when seeing a temple because he frequently is exposed to such situation in a story he was read to or read by himself. This is also a prove for a strength of the children's book Mencar. The story Mencar also contains good social values as shown in the characters in the story who were children from different religious background. They are friends in good and bad times. It is contented that social attitude is built from social interaction that a child experienced [2]. Personal experience, mass media, education, religion, and emotional factors of an individual are said to influence someone's social attitude.

Beside attitude, students' reading interest was also proven significantly improved through the use of the story Mencar in classroom sessions. Especially stories of adventure can strongly arouse students' reading interest [3]. The story Mencar told the adventure of Gde Bagus and his friends when following Gde Bagus' father going fishing. Sometimes there were big waves that made the children anxious. 
The story Mencar also presented contexts which were close to the students' real life in Bali. In the story we could find parts containing this issue. For instance, Made Ayu offered saiban, a tradition in Bali where all houses offer food they have in the day to some Gods before they eat. This makes it easy for the students to make connection between their experience with the story because children aged around ten are commonly in charge of making and offering saiban. This makes the students' to be eager to read and read again. This interest to reading had been proven improved by the use of the story Mencar as it contained many local features that interest students to read.

Finally, the story Mencar was also proven to have a strong effect on student's learning outcome. This finding proves that storying is not only effective to tell moral values as most people have already familiar with. Psychologically, storying to children brings them to activate their mental representation of life very easily because the narrative structure of story is perfect with the characteristics of four graders' operational concrete of cognitive development.

The story Mencar also met the social perspectives of learning from Vygotsky, in which learning takes place if there is interaction between the person with his/her environment (internal-external interaction) [4]. Moreover, it shows the relationship between culture and cognition [5]. It is said that cognitive processes will take place meaningfully in the context which is relevant to the culture of the person involved in the process. This concept is very highly facilitated by the story Mencar, as many Balinese cultural contexts and traditional activities were involved.

Supporting the above arguments, there are research findings on the effect of stories and storying upon learning outcome. A strong effect of using strories on students' reading comprehension has been reported [6]-[7]. Moreover, it has also been reported that there is a significant effect of thematic instruction assisted by stories upon students' ability in reading, writing, and math [8].

\section{Conclusion}

Based on the findings and discussion above it is concluded that the thematic children's book entitled Mencar had been proven effective to be used together with K-13 textbook's sub theme Occupations Around Me in grade four. There are some aspects of the children's book which are believed to make it powerful in supporting children's development of attitude and reading interest, and also their learning outcome, namely 1) the inclusion of curriculum contents in the story, 2) the use of supporting local culture in the story, and 3) the choice of narrative structure (storying) to present the curriculum contents. The effort to develop and provide thematic, narrative reading materials like this is very strongly needed because two things can be facilitated at the same time, those are literacy and learning. The use of thematic children's book such as Mencar has been proven to meaningfully bridge between literacy and curriculum, especially in elementary school level.

\section{References}

[1] Walker C M and Lombrozo T 2017 Explaining the moral of the story J. Sci. Direct

[2] Azwar S 2009 Sikap Manusia: Teori Dan Pengukurannya Yogyakarta: Pustaka Pelajar

[3] Ledger S and Merga M K 2018 Reading aloud: children's attitudes toward being read to at home and at schoolAustralian J. of Teacher Education43123-139

[4] Liu C H and Matthews R 2005 Vygotsky's philosopy: contructivism and its criticisms examined Int. Education J. 6386-399

[5] Sri W D 2015 Teori belajar konstruktivis piaget dan vygotsky IndonesiaDigital J. of Mathematics and Education2191-198

[6] Ardhitama Y A, Wardani S, Purwanti E, Hindarto N 2018 Storybook influence on scienceconcept comprehension through curiosity of fifth grade elementary school student $J$. of Primary Education71-9

[7] Roslina 2017 The Effect of picture story books on students' reading comprehension J. Advances in Language and Literacy Studies8213-221 
[8] Arnasih N W, Marhaeni A A I N, and Arnyana, I B P 2015 Pengaruh implementasi pembelajaran tematik berbantuan cerita terhadap aktivitas dan prestasi belajar calistung siswa kelas III SD di Gugus V Kecamatan Tegalalang Kabupaten Gianyar.Jurnal Ilmiah Pendidikan dan Pembelajaran PPs Undiksha. 